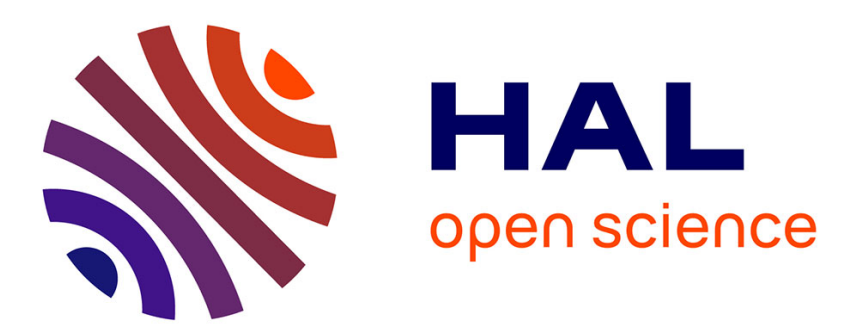

\title{
Reinventing marine spatial planning: a critical review of initiatives worldwide \\ Brice Trouillet
}

\section{To cite this version:}

Brice Trouillet. Reinventing marine spatial planning: a critical review of initiatives worldwide. Journal of Environmental Policy and Planning, 2020, 22 (4), pp.441-459. 10.1080/1523908X.2020.1751605 . hal-02543945

\section{HAL Id: hal-02543945 \\ https://hal.science/hal-02543945}

Submitted on 23 Oct 2020

HAL is a multi-disciplinary open access archive for the deposit and dissemination of scientific research documents, whether they are published or not. The documents may come from teaching and research institutions in France or abroad, or from public or private research centers.
L'archive ouverte pluridisciplinaire HAL, est destinée au dépôt et à la diffusion de documents scientifiques de niveau recherche, publiés ou non, émanant des établissements d'enseignement et de recherche français ou étrangers, des laboratoires publics ou privés. 


\section{Pre-print version}

2 Trouillet, B. (2020). Reinventing marine spatial planning: A critical review of initiatives worldwide.

3 Journal of Environmental Policy \& Planning, 22(4), 441-459.

4 https://doi.org/10.1080/1523908X.2020.1751605 


\title{
5 The past, present and future of marine spatial planning: a critical review 6 of initiatives worldwide
}

Brice Trouillet, Université de Nantes, CNRS, UMR LETG, Chemin de la Censive du Tertre, BP 81227, 44312 Nantes Cedex 3, France - Brice.Trouillet@univ-nantes.fr

\begin{abstract}
Although marine spatial planning (MSP) is increasingly being applied worldwide, it appears to be based on an ambiguity that has arisen from its dichotomous role of ensuring both conservation and development. This elusive ideal hints at a possible discrepancy between theory and practice. This paper explores the hypothesis that beyond a performative narrative, MSP is actually better described as a variety of devices which fulfil other roles and converge in terms of planning type. To test this hypothesis, this paper analyses the content of past and present MSP initiatives from around the world. The findings show that these initiatives view MSP either as a strategic sectoral spatial planning tool or strategic planning tool, brought in to complement existing initiatives. Furthermore, these two approaches can actually be seen to converge in the type of planning used, through the role attributed to spatial aspects, and more specifically in the place given to zoning. There are two key implications of these findings: the need to open up theoretical debates more broadly to different disciplinary perspectives on MSP; and the need for crucial choices to be made to ensure that MSP does not become an illusion behind which other agendas lie.
\end{abstract}

Keywords: Marine Spatial Planning, Spatial planning, Strategic planning, Zoning, Critical review

\section{Introduction}

With just over sixty initiatives already completed worldwide (IOC-UNESCO \& EC-DG Mare, 2017), marine spatial planning (MSP) has now asserted itself worldwide with regards to two major ocean-based phenomena ${ }^{1}$. These are both causes and consequences of the "social construction of the ocean" (Steinberg, 2001) and take on a variety of forms when brought together. The first phenomenon is the increasing need for space due to the development of 'new' uses (marine renewable energies, offshore aquaculture, extraction of minerals, fibre optic cable, etc.) (e.g., Smith, 2000). The second one is the development of tools - particularly marine protected areas (MPAs) - for protecting marine ecosystems and biodiversity, with the aim of incorporating $10 \%$ of the world's ocean surface area by 2020 (i.e., about 36 million $\mathrm{km}^{2}$ ), compared with the current $4.8 \%, 2.2 \%$ of which is 'highly protected' (i.e., 'no-take marine reserves') ${ }^{2}$.

Both of these two phenomena should continue to drive the need for developing MSP over the coming years. This assumption is strongly supported by global goals for marine protected areas (UNSDG Target 14.1). Regarding marine conservation on the one hand, current debates mainly revolve around either the effectiveness of MPAs with regards to the various anthropogenic impacts and the multiple forms they take (Pendleton et al., 2017;

\footnotetext{
${ }^{1}$ These tools are cited, for example, as being behind the need for planning in the first preamble of European Directive 2014/89 on establishing a framework for maritime spatial planning.

${ }^{2} \mathrm{http}$ ://www.mpatlas.org/map/mpas/ (retrieved in September 2019). Other terms are also sometimes put forward, such as 'fully protected areas' (see Pendleton et al., 2017). The overall idea is to exclude 'extractive activities' - a term which is rather surprising as it seems to put all types of 'extraction' in the same basket.
} 
Woodcock et al., 2017), along with their different characteristics (Edgar et al., 2014) ${ }^{3}$; or the way in which functional goals of MPAs are defined and the consequences it may have (Agardy et al., 2013; Agardy et al., 2016; Jameson et al., 2002). Despite this, a few voices favouring a more ambitious goal are already being heard: at least $30 \%$ of ocean surface area should be left free of 'extractive activities' (O'Leary et al., 2016; World Parks Congress, 2014), or even $50 \%$ (Wilson, 2016). These voices actually seem to find a certain echo in the political sphere, as according to the International Union for Conservation of Nature, 129 governments or government agencies signed a motion in favour of raising the target to $30 \%{ }^{4}$ at its congress held in Honolulu (USA) in September 2016, whereas only 16 of them were against it. Thus marine conservation will probably continue to foster the expansion of MSP.

A more circumspect approach is warranted, however, concerning the potential development of ocean uses, in spite of the increasingly prevalent image of the ocean as a future El Dorado offering breath-taking potential for economic growth: "Global value added in the ocean economy 'business-as-usual scenario' is estimated to grow to more than USD 3 trillion (in constant 2010 USD) by 2030 (...)" (OECD, 2016) . $^{5}$ Although these predictions forecast that the added value of the world ocean economy will double (Table 1), the same study also later predicts that its contribution to the overall added value of the economy will remain stable at $2.5 \%(\mathrm{OECD}, 2016)$. This presents things from a rather different angle and relativises the 'blue growth' narrative.

The blue economy predictions are further put into perspective when we note that the largest sectors in 2010 (tourism, oil \& gas and port activities) will probably continue to hold the lion's share in 2030 (Table 1). The offshore wind energy sector is the only newcomer with added value that should grow at a spectacular rate of almost $8,000 \%$ between 2010 and $2030^{6}$ on a worldwide scale, given that in the present case, the three previously mentioned uncertainties are currently more reined in: the resources, impacts and regulatory issues are globally under control. So yes, the future will be blue but, aside from a narrative that has proved rather hollow, not more so than today - proportionally at least.

\section{Table 1 here}

What can appear as somewhat surprising from afar is that these two antagonistic phenomena lead to the same conclusion: MSP is regarded as the solution - or at least part of the common solution - for protecting ecosystems and biodiversity as well as enabling the ocean economy to develop. For instance, this is how things are stated in the MSP European doctrine. The convergence of the following two conclusions serves as a good example and as food for thought:

\footnotetext{
3 "Here we show that the conservation benefits of 87 MPAs investigated worldwide increase exponentially with the accumulation of five key features: no take, well enforced, old (>10 years), large (>100 km2), and isolated by deep water or sand" (Edgar et al., 2014).

${ }^{4} \mathrm{https}$ ://portals.iucn.org/library/sites/library/files/documents/IUCN-WCC-6th-005.pdf

5 The two other scenarios (sustainable/unsustainable) produce similar figures (USD 3.2 and 2.8 trillion, respectively).

${ }^{6}$ Important as it may be, as an absolute value (USD 227 billion), it comes in only third place, notably behind the tourism sector (USD 387 billion) in terms of growth.
} 
- "Not surprisingly, we both come to the conclusion that MPAs fare best when embedded in broader planning frameworks that can address both internal pressures and external threats. Viva la MSP!" (Agardy, 2017);

- and "(...) MSP is seen as a process that can enhance sustainable growth as it provides legal certainty, predictability and transparency, thus reducing costs for investors and operators" (Schaefer \& Barale, 2011).

On closer inspection, the oxymoron 'blue growth' highlights this convergence of seemingly paradoxical objectives and squares the circle of an economic growth based on the 'proper' management of social-ecological systems (Eikeset et al., 2018). Furthermore, by broadening reflection to include the notion of performativity (Denis, 2006; Dumez \& Jeunemaitre, 2010; Muniesa \& Callon, 2008), we could say that as a socio-technical device, MSP unleashes the power of 'blue growth' to perform.

In principle, MSP is needed to take overall account of social and economic requirements as well as the protection of the marine environment. It enables an all-encompassing strategy to be defined, avoiding patchy and uncoordinated decisions (Kannen, 2014). However, at the same time, MSP appears to be based on an ambiguity that has arisen from its dichotomous role of ensuring conservation and development. Although this can become some sort of ideal to be attained, in reality, it is hard to imagine how MSP could incorporate all the stakes and more specifically, fulfil this dichotomous role. Consequently, our hypothesis in this paper is that beyond a theoretical performative narrative, MSP actually corresponds rather to a variety of devices which (i) seem to have other roles to play than that of an ideal balance between conservation and development; and (ii) converge, despite their heterogeneity, in certain ways through the type of planning used (strategic, sectoral, spatial...) and their implications. Discrepancies hence appear between theory and practice, requiring a more critical approach to decipher the true functions of these MSP processes and understand how they operate. To identify and understand these possible discrepancies and their implications, this paper will analyse the content of past and present MSP initiatives from all around the globe. First of all, we will describe and justify the method of analysis (2). The findings will then be presented (3) and discussed (4). This will be followed by the conclusion, which puts these findings into perspective with a broader reflection on planning (5).

\section{Materials and methods}

To test our hypothesis, different past and present initiatives were analysed in detail. Three published studies analysed these practical initiatives on a global basis:

- Collie et al. (2013) conducted a study on 16 cases from around the world using an analysis framework comprised of 42 questions on objectives, scope, managing authority, type of participants, data, decision-making tools, monitoring and evaluation of measures. This grid drew on four works on MSP (Beck et al., 2009; Ehler \& Douvere, 2009; Gold et al., 2011; Halpern et al., 2012). The study led to the following conclusions: (i) although used, decision-making tools were not always applied in a logical manner, (ii) most of the time, the different approaches did not lead to the selection of the preferred scenario, (iii) the plans stemming from the approaches were diverse in nature; 
- Jones et al. (2016) analysed 12 cases in Europe only, using an analysis framework established in an empirical way and structured by the following themes: governance, conflicts, degree of integration, participation, equity and uncertainty. Their conclusions were centred around four main points: (i) in reality, the approaches were more similar to strategic sectoral planning initiatives than MSP, (ii) the planning process was actually more pragmatic - in other words, it moved away from a process theoretically built around cyclical stages towards a mixed formal and informal framework, (iii) participation had a limited influence on decisions, (iv) zoning reflected top-down decision-making;

- Domínguez-Tejo et al. (2016) studied 12 cases throughout the world using an analysis framework based on seven of the 12 principles of the ecosystem-based approach (or Malawi principles). This study found that: (i) in the field, MSP revealed a diversity of practices; (ii) non-commercial, cultural or heritage values were rarely taken into account (and scarcely documented from a spatial perspective) compared with economic and environmental values; (iii) the issue of combined impacts was barely taken into account; and (iv) environmental values (especially biodiversity and water quality) were mainly considered through the lens of MPA networks.

These three studies conducted on a limited number of cases already converge at least one point - which is not surprising given the multiplicity of situations throughout the world: MSP practices are in fact very diverse. This diversity can lead to deviations from the theory, which varies depending on the case. In addition, other than in Jones et al. (2016) and because their objectives were focused on MSP principles and norms, these works tell us little about the actual roles fulfilled by MSP. Our paper thus attempts to document this aspect more specifically, while at the same time broadening the scope of analysis to include all practical MSP initiatives from around the world.

\subsection{Corpus of documents}

To do this, our analysis focuses on MSP initiatives recognised by UNESCO, which reports and monitors them on its website 7 . According to this, there are 150 MSP initiatives in phases spread between preparatory and final phases (on 1 April 2018) (see Appendix 1a). On this basis, we only retained the completed documents pending approval (i.e., phase 4 of UNESCO's seven-phase approach) or later stage documents (= 59 documents) for our study. This choice was justified by two factors: firstly, we decided to study primary sources, i.e., the planning documents themselves (Appendix 1b), rather than secondary sources (e.g., scientific publications analysing practical initiatives) which naturally imply the existence of a completed document (i.e., a management plan completed). Secondly, the number of initiatives having reached phase 5 (or approved status) and whose final document was available was limited (25 cases). Consequently, 19 initiatives out of the 59 initially retained were rejected, mainly due to document availability issues. However, three more were added after we noticed recording errors made by UNESCO (i.e., phase 5 had been validated but not phase 4). Lastly, the Chinese MSP initiatives required a slightly

\footnotetext{
${ }^{7}$ http://msp.ioc-unesco.org/world-applications/status of msp/
} 
different approach: it seemed both impossible to analyse them, because of lack of access to final documents, and difficult to ignore them completely (16 documents inaccessible in total, including 12 in China). Given that they appeared to have an overall logical coherence, we decided to treat all the Chinese cases as one single case, using scientific publications regarding Chinese plans (Appendix 1a and 1b). The question also arose of considering different initiatives within the same country as a single case. We have chosen as a general principle in advance to keep all initiatives as different cases for two main reasons: on the one hand the political organization of countries (e.g., federal model) can generate initiatives with different characteristics, on the other hand, different initiatives within a same country may have taken place at different times also potentially leading to different characteristics.

In all, the corpus of data comprised 44 MSP cases from around the globe $(=59-19+3+1)$ (Figure 1). This corpus itself will be discussed later. One may observe that such MSP initiatives are mainly concentrated in some regions, namely Northern and Western Europe and Northern America firstly, and secondly Middle America, South-eastern Asia and Oceania. Also, according to the UNESCO database and considering plans only at phase 4 or later stage, large parts of the world ocean are blank of MSP initiatives (i.e., Africa, Asia, and Southern America).

176 Figure 1 here

\section{7}

178

179

180

181

182

183

184

185

186

187

188

189

190

191

192

193

194

195

196

\subsection{Analytical framework}

Once this corpus had been determined, we set out to establish a specific analytical framework. This was empirically structured, drawing on a literature review oriented around the subject: the roles of MSP and the types of planning concerned. This review revealed ambiguities at both levels, perpetuated by a lack of theoretical explanation. This paper aims to discuss these three aspects (MSP roles, planning types and ambiguities linked to these two points) in detail to establish the basis for our analytical approach and for defining indicators.

\subsubsection{Roles of MSP}

The first aspect is the roles played by MSP. The literature review revealed the coexistence of concepts inherited from the two phenomena behind the development of MSP. Additionally, as demonstrated by the European example, some consider the ecosystem as a use among others (integrated-use MSP - soft sustainability), whereas others see the ecosystem-based approach as a precondition (ecosystem-based MSP - hard sustainability) (Frazão Santos et al., 2014; Qiu \& Jones, 2013). In the European case, this ambiguity was already present at the incubation stage, before Directive 2014/89 (MSPD) was even enacted, as fundamental divergences had been observed between Directive 2008/56 (MSFD) and the Integrated Maritime Policy, on the actual role of MSP or MPAs (Qiu \& Jones, 2013) for example. Today, in the European context, the MSFD serves as an environmental guideline ${ }^{8}$ for the MSPD, and MPAs are viewed as one 'use' among others

\footnotetext{
${ }^{8}$ http://eur-lex.europa.eu/legal-content/FR/TXT/?uri=LEGISSUM:128164
} 
in marine planning documents ${ }^{9}$. However, in practice, member states are free to interpret and implement in a broad variety of ways. Under these conditions, it is not surprising that the interaction between MSP and MPA can take many forms: for instance, MPAs with multiple objectives are sometimes considered as a form of MSP.

201 More generally, although numerous authors indicate that MSP is taking root in the tenets of 'ecosystem-based management' ${ }^{10}$ (e.g., Crowder et al., 2006; Degnbol \& Wilson, 2008; Douvere, 2008; Douvere \& Ehler, 2009; Elher \& Douvere, 2009; Gilliland \& Laffoley, 2008; Symes, 2005), and the example of the Great Barrier Reef (Australia) is often presented as being the first ocean-based planning initiative ${ }^{11}$ (Day, 2002; Olsson et al., 2008), though it would be hard to identify MSP solely in this way.

Ocean-based planning is not actually a completely new idea, even in its integrated form, and it evokes practices that are already relatively time-tested and established. As of the 1970 s (during the early years of offshore oil extraction in the North Sea), the notion of 'seause planning' - or 'sea-use management' - was born, notably amongst British geographers (i.e., Cicin-Sain et al., 1992; Eisma et al., 1979; Smith, 1988; Smith, 1990; Smith, 1991a \& 1991b; Smith, 1994; Smith \& Lalwani, 1996; Young \& Fricke, 1975). It not only took the specificities of the marine environment into account, but also more traditional planning theory concepts, which had been mainly developed for land planning purposes (Kidd \& Ellis, 2012; Kidd \& Shaw, 2014; Gazzola et al., 2015; Smith et al., 2011)). In the same period, riding on the wave of a new discipline (conservation biology), 'systematic' conservation planning surfaced in response to the need to curb the decline in biodiversity. It gradually integrated socio-economic criteria and finally grew by increasingly using quantitative approaches to identify priority conservation areas according to more explicit criteria (hence the use of the adjective 'systematic') (Margules \& Pressey, 2000; Sarkar et al., 2006). This approach, which promoted one conservation tool amidst others (the protected area), appropriated tools dating back to the end of the 19th century (parks, reserves, etc.). It then looked to rationalise the methods for identifying and harmonising forms at an international level. The tools then logically ended up being applied to oceans (i.e., MPA) (Dudley, 2008; Kelleher \& Kenchington, 1991). Furthermore, in the same way that environmental planning formerly sought to make planning (urban or territorial) more ecological without strengthening its theoretical principles (Briassoulis, 1989; Faludi, 1987; Slocombe, 1993; Whatmore \& Boucher, 1993), it would appear that MSP can be schematically perceived as an as yet unsuccessful ocean-based attempt either to 'ecologize' the planning of uses, or to 'socialise' conservation planning. There is still a fundamental ambiguity surrounding the roles of MSP, notably on how the 'environment' is considered.

\subsubsection{Approaches to Planning}

The second aspect to be discussed relating to our literature review is the type of planning used. Different names are given to MSP in scientific literature and official documents (Jay, 2013). The expressions 'marine spatial planning', 'maritime spatial planning', 'marine and

\footnotetext{
${ }^{9}$ See Article 8 of the MSPD.

${ }^{10}$ The quotation marks underline the fact that the notion of ecosystem-based management (EBM) is not stable and can take on different meanings within the scientific community (Long et al., 2015). Also see the interesting contribution made by Slocombe (1993) on this topic.

${ }^{11}$ The park was established in 1975 and the first zoning plan was drawn up in 1981 (Day, 2002).
} 
coastal spatial planning' and 'maritime space planning' - to mention the most frequently used terms - are often used analogously. The adjectives 'maritime' and 'marine' are often used interchangeably from one expression to another. The first adjective evokes things associated with the sea, possibly including the coast itself, and therefore covers a wider notion, including spatially. However, in a more restrictive way, the second adjective only refers to what directly relates to the sea, in addition to probably placing a stronger emphasis on the 'environment'. For instance, a fish is a marine resource while a boat is a maritime resource, as well as a marine pollution is a pollution of the sea while a maritime pollution is a pollution (of the coast) that comes from the sea. Consequently, marine planning and maritime planning cannot be strictly equivalent. Furthermore, the first three terms put the emphasis on spatial planning (Smith et al., 2011) which, with a rationalist basis and suggesting the division of uses in space, can lead almost automatically to zoning (see Jay, 2013). In addition, one should also consider a distinction between spatial planning at sea and marine spatial planning; the latter suggesting a specific way to conceptualize and practice spatial planning. The approach of spatial planning has also evolved over time, changing in essence by being applied to the maritime domain (Kidd \& Ellis, 2012), and no longer having the same meaning depending on the planning culture. Accordingly, to put emphasis on spatial planning at sea rather than maritime planning has serious implications. As for the fourth term, by contrast, it originates from the desire to promote strategic (spatial?) planning, automatically relegating the spatial aspect to second place (Albrechts, 2004; Healey, 2004). In other words, it would theoretically explore the 'why' before tackling the 'how'. Far from being a simple question of form or technique ${ }^{12}$, this is actually a fundamental reflection on the place of both strategic and spatial aspects in ocean planning. The balance between spatial and strategic aspects appears unclear where MSP is concerned, revealing contexts in which the spatial aspects - and even zoning - are activated in potentially different ways depending on the case.

Beyond this, the fundamental question of historical context is also raised. Taken from a general point of view, MSP is similar to other forms of planning in that it does not emerge from a void. In Europe for example, a certain number of countries had already developed national strategies for conserving biodiversity or developing offshore wind farms (to mention just two examples) before defining their global maritime strategies. Although this scenario is not unusual in the world of planning, it nevertheless raises the question of whether one of the hidden roles of this type of approach could actually be to offer 'staging' for decisions already took or underway, in the same vein as strategic planning (particularly in terms of communication) or new spatial planning (Albrechts et al., 2003; Allmendinger \& Haughton, 2012; Demazière \& Desjardins, 2016; Demazière et al., 2016; Faludi, 2000; Healey, 1997; Salet \& Faludi, 2000). Taking a closer look at the details reveals that whereas conservation only makes sense in the long term, as the positive effects of an MPA only surface after several years (Edgar et al., 2014; Pendleton et al., 2017), the planning of

\footnotetext{
${ }^{12}$ Whereas the title of the English version of the MSPD (2014/89) is 'Maritime spatial planning', the titles of the Directive in other languages (Italian, French, Portuguese, Spanish, etc.) refer to "planning of maritime space', which tends to evoke the space to which planning is applied rather than how the planning in itself can be envisaged.
} 
uses mainly involves readjustments over a shorter term ${ }^{13}$, even if the long term also needs to be considered.

\section{$277 \quad$ 2.2.3 Theoretical Foundations and Ambiguities}

278 The third and final aspect to be considered in our literature review is the theoretical 279 foundations. It is not surprising that under the above-mentioned conditions, MSP is still 280 suffering from a lack of clarity: “(...) [its] literature has generally lacked deeper reflexive 281 engagement with the emerging system of governance for our seas that has meant that many 282 of MSP's core concepts, assumptions and institutional arrangements have not been subject 283 to rigorous intellectual debate" (Kidd \& Ellis, 2012). This situation can probably be 284 explained by the fact that scientific communities and a variety of practitioners gravitate, sometimes opportunistically ${ }^{14}$, around MSP without necessarily being able to clearly articulate their relation to a common subject. This observation is backed up by a graph analysis applied to scientific publications on MSP, which shows that publications cluster in different groups based on an association of keywords (Figure 2). Four main groups are revealed $^{15}$ : one centring on management issues (group 1 - green/blue), one on methodological issues (group 2 - green), another on conservation issues (group 3 - yellow) and a fourth one focusing more specifically on fisheries (group 4 - orange). These publication groups obviously have blurred and porous boundaries and the names they are given are suggestive: they are neither mutually exclusive, nor easily associated with clearly-defined scientific communities. That said, they nonetheless appear to indicate that MSP is approached from dramatically different perspectives. All this could appear quite normal if it had not been concomitantly noted that the levels of theoretical reflection on planning (roles, types), and its political dimensions, are only secondary or even marginal, when it should play a more primary role and give rise to more rigorous debate, thus enabling the core concepts to be properly grounded.

Figure 2 here

From this point of view, the definition of MSP most often quoted in the literature is symptomatic: "Marine spatial planning is a public process of analyzing and allocating the spatial and temporal distribution of human activities in marine areas to achieve ecological, economic, and social objectives that usually have been specified through a political process" (Ehler \& Douvere, 2009). Its main characteristics are then described using a variety of soft concepts ${ }^{16}$, which become 'buzz words' whose status is rarely brought into question. In the same vein, the adverb 'usually', which features in the definition, relegates the political dimension of planning to second position or even the sidelines. Consequently, MSP seems to be lowered to the rank of a technical protocol (e.g., Caldow et al., 2015; Center for Ocean Solutions, 2011; Pınarbaş1 et al., 2017; Stelzenmüller et al., 2013) and is apparently depoliticised. It is clear that none of the scientific approaches and stances taken in relation to MSP, however legitimate or pertinent, can claim to be neutral, as the way in which the question is actually raised places MSP under the focus of objectives, methods or

\footnotetext{
${ }^{13}$ Besides, in Europe, the MSPD proposes that plans be reviewed every 10 years at the most.

${ }^{14}$ In terms of MSP, as for many seemingly new and politically-integrated ideas or fields of study, a 'label' or fad effect can naturally emerge, which contributes to muddying the waters.

${ }^{15}$ In addition to a smaller and more marginal fifth group (in blue).

${ }^{16}$ Notably: ecosystem-based, integrated, area-based, adaptive, strategic, anticipatory, participatory, etc.
} 
tools, which in themselves have a political meaning. Neither can it be denied that theoretical blind spots in MSP can also be exploited by non-transparent strategies or 316 policies.

317 This lack of theoretical clarity contributes to sustaining ambiguities on the real roles of 318 MSP and on the type of planning which serves to fulfil these roles, all the more so given that this question has been dealt with by mainly the scientific community and professional practitioners. Our paper has thus attempted to establish an analytical framework focusing mainly on these two crucial MSP ambiguities.

To do this, we defined and proposed to apply seven indicators to the corpus of documents (Table 2). Whereas indicator I1 is factual and may enable the size of the planning zone to be put into perspective, the six other indicators are interpretative and completed based on an analysis of the content of the corpus. Two of the six indicators attempt to identify the real roles of MSP (indicator I2 and I3) and five of the six try to pinpoint the type of planning that enables these roles (indicators I3, I4, I5, I6, and I7). Other elements could also have been involved in the analysis, such as the planning trajectory or planning culture. Two main reasons led to dismissing them. First, these elements are generally not apprehensible in planning documents. Secondly, for a general-level study with other benefits such as providing a common analytical framework for comparison, it does not seem possible to address this point which would require much more extensive and probably unrealistic investigation. Thus, these other elements can be taken into account in targeted case studies using materials other than planning documents alone. To measure the indicators, the structure of the documents contained within the corpus (Appendix 1a) was analysed and we gave whole parts of documents a close reading (e.g., sections relating to strategic objectives, maps).

\section{Table 2 here}

\section{Results}

Given the sum of compiled elements, we decided to present only the synthesis of the results in this section and to list details in the appendices. In addition, to fully understand the main factual results delivered in this section, it is important to read the text and the contents of the tables in parallel and, if necessary, to refer to the corresponding appendices.

The analysis of documents (Table 3) gave the following outline results - only the trends and general proportions were considered rather than undertaking a statistical analysis, which would not have been meaningful given the reduced number of MSPs included (between 30 and 44 depending on the indicators):

- Indicator I1 (Appendix 1c): the MSP initiatives considered covered geographical zones ranging from $674 \mathrm{~km}^{2}$ (Philippines, PH2) to 2 million $\mathrm{km}^{2}$ (Australia, SouthEast region, AU3). However, more than half covered a surface area of less than $60,000 \mathrm{~km}^{2}$ and a third even covered a surface area of less than $10,000 \mathrm{~km}^{2}$.

- Indicator I2 (Appendix 1d): a clear majority of initiatives had a broad thematic scope, often covering a wider range of stakeholder interests. The rest, except for one (US-41, Oregon), were conservation-focused strategic plans (four of the Australian plans, AU-4 to AU-7, and the one for the Galapagos Islands, EQ-35). Even though 
these few cases covered very widespread geographical sectors, there did not seem to be a clear correlation with the size criterion applied to planning zones.

- Indicator I3 (Appendix 1d): about two-thirds of the analysed documents regarded MSP from a soft sustainability perspective, namely a development-oriented document (marine energy, shipping, aquaculture, etc.) seeking to take into account conservation issues. When we excluded the conservation-focused strategic plans, which were questionable to equate with MSP (see I2), this proportion was even greater. Two initiatives could not be classed under one of the two categories as they focused on a knowledge gaining objective, by setting up spatial data portals (USA, US-43 and US-44). Otherwise, there was a strong correlation with the size of the planning zones, as almost all the plans covering a zone with a surface area of less than $60,000 \mathrm{~km}^{2}$ regarded MSP from a soft sustainability perspective, whereas more than two-thirds of the plans covering a zone with a surface area of more than $60,000 \mathrm{~km}^{2}$ leant towards hard sustainability. Regardless of the difficulty in generally interpreting the type of sustainability, it emerges from this exercise that we have rarely hesitated on any of the sustainability approaches in each planning process. Often, this clearly appears in the very content of the documents, and particularly in the relative place given to different priorities whether it concerns conservation or economic development: these are never at the same level.

- Indicator I4 (Appendix 1e): only slightly more than half of the analysed initiatives had orientations which defined and described spatially-explicit strategies. The others were either strategic documents without a spatial dimension (e.g., marine energy development), or in some cases, documents without an explicit strategic dimension other than some main guiding principles (Germany, GE-14 and GE-15, Normay, NO-20 and NO-21, UK, Scotland, UK-25, Mexico, ME-36-38). More than three-quarters of the initiatives establishing spatially-implemented strategic orientations concerned zones of less than $60,000 \mathrm{~km}^{2}$ and conversely, three-quarters of the initiatives not establishing a spatially-implemented strategic approach concerned zones of more than $60,000 \mathrm{~km}^{2}$.

- Indicator I5 (Appendix 1e): almost half of the MSP initiatives had a strategic orientation that was spatially implemented through zoning. Three-quarters of them concerned plans established over zones of less than $60,000 \mathrm{~km}^{2}$. Others may have strategic orientations which, when they are spatially-explicit, are expressed in the form of one or more spatialized scenarios or by indicative and sometimes even approximate maps (e.g., United Kingdom, UK-22, UK-23, UK-24, UK-26, Belize, BE-28, Mexico, ME-36, ME-37, ME-38, USA, US-40 and US-41). By the way, one should also note that it is sometimes possible to have a zoning map without any explicit strategic orientation. This is why I4, I5 and I6 do not necessarily overlap but are rather complementary.

- Indicator I6 (Appendix 1e): almost all the initiatives implemented accurate zoning or by default, presented a 'spatial vision' (scenario, maps, etc.) based on precise mapping (it is worth noting that some approaches were part of a 'spatial vision' which was not necessarily strategic or a fortiori, prescriptive, e.g., an illustrative scenario; again this is why indicators I4 and I6 did not totally concur). Accurate zoning was particularly used in plans covering zones with a surface area of less than $60,000 \mathrm{~km}^{2}$. Only two initiatives had accurate zoning or mapping that expressed a 
schematic 'spatial vision'. Besides, almost three-quarters of MSP initiatives undertaken with a soft sustainability approach (see I3) implemented accurate zoning or by default, a 'spatial vision' (scenario) based on precise mapping. The correlation was less clear-cut in terms of MSP initiatives based on a hard sustainability approach.

- Indicator I7 (Appendix 1e): Slightly over half of zoning or mapping which expressed a 'spatial vision' were not prescriptive and tended more towards being indicative. The prescriptive MSPs were plans aiming either to bolster or implement a MPAs network, or to enable new activities to be developed (especially offshore wind energy). In addition, two-thirds of the prescriptive MSPs were plans concerning zones of less than $60,000 \mathrm{~km}^{2}$.

Table 3 here

Beyond this first basic classification, other more cross-cutting results were obtained by combining the different indicators to classify the MSPs into types. To do this, we looked at indicators I3 (sustainability), I4 (type of planning), I5 (zoning) and I6 (type of zoning). We set aside the other three indicators after observing that empirically, they tended to provide complementary information rather than any major insight: size (I1), thematic scope (I2) and the prescriptive or indicative nature of zoning (I7). Furthermore, two initiatives were not taken into account in this classification given that they were approaches closely linked to an activity providing support to MSP (i.e., spatial data portals) rather than being 'true MSP' approaches in themselves. In the end, four main types clearly stood out (Figure 3):

- Type 1 (20 cases): MSP initiatives viewed from a soft sustainability perspective (I3) with a strategic dimension implemented spatially (I4) in the form of accurate (I6) zoning (I5). The main focus of the objectives for all but three (Belize, Croatia and Nunavut) of this type of initiative was to identify geographical areas for developing marine renewable energies;

- Type 2 (7 cases): MSP initiatives viewed from a soft sustainability perspective (I3), but without a spatially-implemented strategy (I4). Aside from two Norwegian cases, these were mainly local-scale plans with marine renewable energies as a core development objective;

- Type 3 (11 cases): MSP initiatives viewed from a hard sustainability perspective (I3) without a spatially-implemented strategy (I4). Aside from two specific cases (Philippines and Galapagos Islands), these were mainly general documents providing guidelines for existing or soon-to-be MPAs (which employ spatially explicit zoning);

- Type 4 (4 cases): MSP initiatives viewed from a hard sustainability perspective (I3) with a strategic dimension implemented spatially (I4) in the form of accurate (I6) zoning (I5). These cases tended to resemble multi-objective MPAs.

Figure 3 here

Accordingly, the analysis of these 44 initiatives conducted throughout the world indicates that MSP is probably not able to fulfil the double role of conserving marine ecosystems and biodiversity on the one hand, and enabling economic activities to develop on the other. If we look at the facts, despite taking on a wide variety of forms, initiatives tend either towards one or the other. This serves to confirm that two main sustainability concepts 
coexist in MSP, but that they are hard to reconcile and attract a host of intertwined subtleties. These findings seem to indicate that the real roles of MSP currently are:

- either to accompany the development of economic activities, particularly renewable marine energies, by parading MSP as a process that is ecosystem-based (soft sustainability), integrated, area-based, adaptive, strategic, anticipatory, participatory or another contributing concept that follows a consensus-building logic;

- or to a lesser degree, to provide the context for an MPA network within a much larger space. MSP is assigned the task of refocusing the different MPAs towards broader conservation goals to take account of the pressure placed on ecosystems outside of MPAs.

In the first case, MSP is conceived as a strategic sectoral planning tool whose main mechanism is zoning. In the second case, MSP appears above all to be a strategic planning tool which supplements existing zoning systems (MPA). In a tentative way, although the first part of our hypothesis seems to be confirmed, the second part (i.e., the hypothesis that approaches based on different rationales converge in terms of planning type) cannot be entirely confirmed at this stage.

\section{Discussion}

The approach taken in this study and the findings made can be discussed from three different perspectives.

Firstly, the corpus of documents gathered and analysed give rise to debate about core definitions. This corpus was actually established based on UNESCO monitoring data, and we have chosen to take it into account as is. However, distinguishing between what is considered as MSP or another management approach is in fact neither trivial nor neutral: some approaches may be called MSP but actually correspond to something else, whereas others may not claim to be MSP but strongly resemble it. Several marine and coastal management processes may be linked to one another and differences between processes are often subtle; thus it is sometimes not easy to distinguish with MPA planning for instance. Beyond this, an initiative can change in character over time, anchoring any observations made to a specific moment in time. These challenges are not unique to MSP, as they are found in a whole host of planning approaches that have blurred outlines - especially when they are taken as being universal. This is true of integrated coastal zone management (ICZM) for example, where Sorensen (2002), after analysing worldwide initiatives, concluded that: "it is not imperative to make an exact separation between what is, or is not an integrated coastal management [ICM] effort. Other types of environmental planning and management efforts, such as marine protected areas or nation-wide integrated environmental action plans, commonly address many of the same issues in the same ways as ICM efforts." In the same vein, the fact that only the initiatives having reached at least the document finalisation stage (i.e., phase 4) were retained may create biases, as this kind of approach has to be part of a process which goes above and beyond the mere production of a document. Besides - and this could be the main criticism - focusing on the analysis of only these documents can lead us to forget the larger institutional context in which they were produced, whether we are referring to other more or less parallel approaches that can nevertheless have impacts (e.g., MPA, terrestrial planning, sectoral policies, etc.), or 
trajectories and timeframes which are specific to each different approach (e.g., an MPA that gradually mutates into an MSP approach). It would be useful to be able to compare and refine these findings with those derived from a different corpus taking into account a wider governance context or with another analysis angle (e.g., other documents than final documents only).

Secondly, the method itself is limited in certain ways. This study did not presume to encompass all possible fields of analysis for MSP initiatives. The aim was to focus on the elements that directly addressed our initial questions. In doing this, it is possible that other elements may have been overlooked in the process of interpreting the content of the analysed planning documents and filling in the indicator table. Besides this, the fact that we interpreted the content of documents is also a limiting factor in itself. Although some indicators were relatively easy to fill in (i.e., I1, I2, I7), others required the unravelling of subtleties, the outcome of which was not certain - even by attentively reading documents. This was especially true when there were references to fuzzy categories, such as the distinction there may be between soft and hard sustainability, or the relative weight strategic and spatial dimensions have in planning (i.e., I3, I4, I5, I6). Beyond this, the act of interpreting itself could not take place without acknowledging the role played by the disciplinary background: for example, it is likely that two different disciplinary stances will lead to two different readings. This is why a maximum number of elements justifying the interpretation were recorded to be referred to on a case by case basis (see the comment columns in Appendix 1d-e). Future research should aim to conduct analysis within a collective framework enabling contradictory arguments, or simply different disciplinary opinions, to be expressed.

\section{Figure 4 here}

Thirdly and finally, concerning the findings themselves, it could be tempting to go further than the main trends exposed, by combining roles and planning types to draw conclusions supported by statistical analysis. However, given the relatively small number of MSP initiatives chosen, the nature of the corpus of documents (e.g., the case of the Chinese initiatives, which were all rolled into one) and, more generally, the interpretation of the above-mentioned discussion points, this would not make much sense. Yet, this remark does at least invite us to turn our attention back to the second part of our hypothesis, which could not be fully confirmed. For, although the hypothesis that approaches based on different rationales converge in terms of planning type could not be officially confirmed, it still ultimately led us back to what is understood as being a part of MSP. In fact, in the case of MSP approaches regarded as strategic planning that supplements existing devices, such as MPAs, the fact that spatial planning or zoning took place 'outside of' (and also before) MSP meant that this convergence could not be observed with MSP approaches based on strategic sectoral spatial planning, which draws heavily on zoning. Three points emerge from this. First of all, it invites us to take the broadest possible view of MSP. This means integrating all formal and informal initiatives competing to share or divide maritime space, because planning, development or conservation processes neither exist within a vacuum nor emanate from a void. In other words, whatever the path followed and as long as a broad view is taken, in practice MSP often ultimately seems to express itself through zoning, or be nourished by it. If this is the case, it is problematic for certain interests which are not entirely compatible with this zoning model (e.g., the connectivity of habitats, scattered 
activities), without even speaking of the fact that zoning itself evokes a certain discourse and idea of 'the environment' in terms of conservation (Whatmore \& Boucher, 1993). Secondly, another more schematic way of looking at the two broad categories that have emerged comes to the fore: (i) an MSP which plays the role of a 'zoom-in' tool, leading to a type of zoning that justifies and imposes strategic sectoral decisions taken elsewhere; and (ii) an MSP which serves as a 'zoom-out' instrument, using existing zoning (MPA) to take external pressures into account (Figure 4). Therefore, two different pathways lead to two hidden or non-explicit purposes embodied by MSP today. Thirdly, whichever of these two pathways are taken, the social, societal and, more generally, territorial stakes are actually marginalised: on the one hand, they are rarely the starting point for establishing sectoral strategies and more often than not, play a somewhat simplistic justificatory role (e.g., the number of jobs created), and on the other hand, they are rarely at one with the geographic scale of an MPAs network.

\section{Conclusion}

In the same way that there is no best or single method for undertaking 'strategic (spatial) planning' (Albrechts, 2004), it is clear that there is no single method for carrying out MSP. We must remind ourselves that according to its declared intentions, MSP is a necessarily a process whose role is to provide a framework where it is needed and on the scale required. This framework should enable a diversity of visions of maritime space to be expressed and compared. This in turn should lead to discussions and negotiations on propositions and decisions to resolve and anticipate any conflicts of uses, minimise the impact on marine habitats and maximise the well-being of populations that inhabit, depend on or simply enjoy this space. From theory through to practice, discrepancies arise requiring deeper reflection, because it is clear that MSP is not quite what is seems (yet?). It is highly probable that time is needed for the different processes to settle. However, scientific communities dealing with the subject also need to cast a more critical eye in terms of the theory behind the concepts on which MSP is based. Although this issue is true for planning in the wider sense (e.g., Olesen, 2014), the ocean puts a different spin on it if we consider both the need for theoretical debates to be broadened to include conservation sciences and the nature of maritime spaces themselves, which can be viewed as 'soft spaces' (see Allmendinger \& Haughton, 2012; Jay, 2018; Olesen, 2014). Failing this, there is a risk that ocean planning will become a pretence of democracy - as is potentially the case of strategic spatial planning in the terrestrial domain - by shifting into a post-political register (e.g., Allmendinger \& Haughton, 2012), which is likely to serve the interests of the powerful, as Healey (1994) has already reminded us in a more general manner: "How far is it possible to imagine that a development plan can be anything other than either a project of the powerful or an ineffective dream of the idealistic?". In other words, as with strategic territorial planning (Demazières \& Desjardins, 2016), MSP creates a paradox in that it proves to be probably both illusory and necessary. Accordingly, there is a need to engage in a more in-depth study and to explicit the political dimension of these processes, in order not to "fall into the trap of totally unrealistic and naïve optimism" (Friedberg, 1993 quoted by d'Aquino, 2002). If this was to happen, MSP would be reduced to an approach guided by an instrumental rationality, when, as is the case in land planning, it needs to combine other forms of interconnected rationalities (value, communicative, and strategic) (Albrechts, 2004). One of the options for advancing towards theoretical renewal in terms of MSP 
would be to give more in-depth reflection to the participation of actors and the role played by socio-technical devices (maps, planning documents, data, etc.) in implementing MSP. This would enable future alternatives (value rationality), the diversity of actors (communicative rationality) and the power relations between the different actors when building the strategy (strategic rationality) to be taken into account (Albrechts, 2004).

\section{Acknowledgements}

This research did not receive any specific grant from funding agencies in the public, commercial, or not-for-profit sectors.

\section{References}

Agardy, T., Bridgewater, P., Crosby, M.P., Day, J., Dayton, P.K., Kenchington, R., Laffoley, D., McConney, P., Murray, P.A., Parks, J.E., \& Peau, L. (2003). Dangerous targets? Unresolved issues and ideological clashes around marine protected areas. Aquatic Conservation: Mar. Freshw. Ecosyst., 13: 353-367. http://dx.doi.org/10.1002/aqc.583

Agardy, T., Claudet, J., \& Day, J.C. (2016). 'Dangerous Targets' revisited: Old dangers in new contexts plague marine protected areas. Aquatic Conservation: Mar. Freshw. Ecosyst., 26(S2): 7-23. http://dx.doi.org/10.1002/aqc.2675

Agardy, T. (2017). Agardy's Final Word. ICES Journal of Marine Science, Special issue, fsx 132. https://doi.org/10.1093/icesjms/fsx132

Albrechts, L., Healey, P., \& Kunzmann, K. (2003). Strategic Spatial Planning and Regional Governance in Europe. Journal of the American Planning Association, 69(2): 113129. https://doi.org/10.1080/01944360308976301

Albrechts, L. (2004). Strategic (spatial) planning reexamined. Environment and Planning B: Planning and Design, 31: 743-758. https://doi.org/10.1068/b3065

Beck, M.W., Ferdaña, Z., Kachmar, J., Morrison, K.K., Taylor, P., et al. (2009). Best Practices for Marine Spatial Planning. Arlington, VA: The Nature Conservancy.

Briassoulis, H. (1989). Theoretical Orientations in Environmental Planning: An Inquiry into Alternative Approaches. Environmental Management, 13(4): 381-392. https://doi.org/10.1007/BF01867673

Caldow, C., Monaco, M.E., Pittman, S.J., Kendall, M.S., Goedeke, T.L., Menza, C., Kinlan, B.P., \& Costa, B.M. (2015). Biogeographic assessments: A framework for information synthesis in marine spatial planning. Marine Policy, 51: 423-432. https://doi.org/10.1016/j.marpol.2014.07.023

Center for Ocean Solutions (2011). Decision Guide: Selecting Decision Support Tools for Marine Spatial Planning. The Woods Institute for the Environment, Stanford University, CA.

Cicin-Sain, B., Knecht, R.W., Jolliffe, I.P., Fabbri, P., Archer, J.H., Buchholz, H.J., \& Smith, H.D. (Eds). 1992. The Management of the European Seas. Ocean \& Coastal Management, 18(2-4): 185-406.

Collie, J.S., Adamowicz, W.L., Beck, M.W., Craig, B., Essington, T.E., Fluharty, D., Rice, J., \& Sanchirico, J.N. (2013). Marine spatial planning in practice. Estuarine, Coastal and Shelf Science, 117: 1-11, https://doi.org/10.1016/j.ecss.2012.11.010

Crowder, L.B., Osherenko, G., Young, O.R., Airamé, S., Norse, E.A., Baron, N., Day, J.C., Douvere, F., Ehler, C.N., Halpern, B.S., Langdon, S.J., McLeod, K.L., Ogden, J.C., 
Peach, R.E., Rosenberg, A.A., \& Wilson, J.A. (2006). Resolving Mismatches in U.S. Ocean Governance. Science, 313(5787): 617-618. http://doi.org/10.1126/science.1129706

d'Aquino, P. (2002). Le territoire entre espace et pouvoir: pour une planification territoriale ascendante. L'Espace géographique, 1(31): 3-22. https://doi.org/10.3917/eg.311.0003

Day, J.C. (2002). Zoning. Lessons from the Great Barrier Reef Marine Park. Ocean \& Coastal Management, 45(2-3): 139-156. https://doi.org/10.1016/S09645691(02)00052-2

Degnbol, D., \& Wilson, D.C. (2008). Spatial Planning on the North Sea: A Case of CrossScale Linkages. Marine Policy, 32(2): 189-200. http://doi.org/10.1016/J.MARPOL.2007.09.006

Demazière, C., \& Desjardins, X. (2016). La planification territoriale stratégique: une illusion nécessaire? [Strategic spatial planning: striking back?]. RIURBA, 2: 1-7. Retrieved from http://riurba.net/Revue/la-planification-territoriale-strategique-uneillusion-necessaire/

Demazière, C., Douay, N., \& Serrano, J. (2016). Léviathan ou Picrochole ? La planification spatiale en France, entre vision stratégique et dépendance aux formes du pouvoir local. Un éclairage à partir des schémas de cohérence territoriale. [Leviathan or Picrochole? Spatial planning in France, between strategic vision and dependence on local forms of power. The case of urban development plans]. RIURBA, 2: 1-14. Retrieved from http://riurba.net/Revue/leviathan-ou-picrochole-la-planificationspatiale-en-france-entre-vision-strategique-et-dependance-aux-formes-du-pouvoirlocal-un-eclairage-a-partir-des-schemas-de-coherence-territoriale/

Denis, J. (2006). Préface: Les nouveaux visages de la performativité. [Preface: The New Faces of Performativity]. Etudes de communication, 29: 8-24. Retrieved from http://journals.openedition.org/edc/344

Domínguez-Tejo, E., Metternicht, G., Johnston, E., \& Hedge, L. (2016). Marine Spatial Planning advancing the Ecosystem-Based Approach to coastal zone management: A review. Marine Policy, 72: 115-130. https://doi.org/10.1016/j.marpol.2016.06.023

Douvere, F. (2008). The Importance of Marine Spatial Planning in Advancing EcosystemBased Sea Use Management. Marine Policy, 32(5): 762-771. http://doi.org/10.1016/J.MARPOL.2008.03.021

Douvere, F., \& Ehler, C.N. (2009). New perspectives on sea use management: Initial findings from European experience with marine spatial planning. Journal of Environmental Management, 90(1): 77-88. https://doi.org/10.1016/j.jenvman.2008.07.004

Dudley, N. (Ed.) (2008). Guidelines for Applying Protected Area Management Categories. Gland: IUCN.

Dumez, H., \& Jeunemaitre, A. (2010). Michel Callon, Michel Foucault and the "dispositif": When economics fails to be performative: A case study. Le Libellio d'Aegis, 6(4): 27-37. Retrived from http://citeseerx.ist.psu.edu/viewdoc/summary?doi=10.1.1.396.201

Edgar, G.J., Stuart-Smith, R.D., Willis, T.J., Kininmonth, S., Baker, S.C., Banks, S., Barrett, N.S., Becerro, M.A., Bernard, A.T., Berkhout, J., Buxton, C.D., Campbell, S.J., Cooper, A.T., Davey, M., Edgar, S.C., Försterra, G., Galván, D.E., Irigoyen, A.J., Kushner, D.J., Moura, R., Parnell, P.E., Shears, N.T., Soler, G., Strain, E.M., 
\& Thomson, R.J. (2014). Global conservation outcomes depend on marine protected areas with five key features. Nature, 506: 216-220.

http://dx.doi.org/10.1038/nature13022

Eikeset, A.M., Mazzarella, A.B., Davíðsdóttir, B., Klinger, D.H., Levin, S.A., Rovenskaya, E., \& Stenseth, N.C. (2018). What is blue growth? The semantics of "Sustainable Development" of marine environments. Marine Policy, 87: 177-179. https://doi.org/10.1016/j.marpol.2017.10.019

Eisma, D., van Hoorn, H., \& de Jong, A.J. (1979). Concepts for sea-use planning in the North Sea. Ocean Management, 5(4): 295-307. https://doi.org/10.1016/0302184X(79)90030-1

Ehler, C., \& Douvere, F. (2009). Marine Spatial Planning: a step-by-step approach toward ecosystem-based management. IOC Manual and Guides No. 53, ICAM Dossier No. 6. Paris: UNESCO.

Faludi, A. (1987). A Decision-Centred View of Environmental Planning. Oxford: Pergamon Press.

Faludi, A. (2000). The Performance of Spatial Planning. Planning Practice and Research, 15(4): 299-318. https://doi.org/10.1080/713691907

Frazão Santos, C., Domingos, T., Ferreira, M.A., Orbach, M., \& Andrade, F. (2014). How sustainable is sustainable marine spatial planning? Part I- Linking the concepts. Marine Policy, 49: 59-65. https://doi.org/10.1016/j.marpol.2014.04.004

Friedberg, E. (1993). Le Pouvoir et la règle. Dynamique de l'action organisée. [Power and rule. Dynamics of the organized action]. Paris: Le Seuil.

Gazzola, P., Roe, M.H., \& Cowie, P.J. (2015). Marine spatial planning and terrestrial spatial planning: reflecting on new agendas. Environment and Planning C: Politics and Space, 33(5): 1156-1172. https://doi.org/10.1177/0263774X15612317

Gilliland, P.M., \& Laffoley, D. 2008. Key elements and steps in the process of developing ecosystem-based marine spatial planning. Marine Policy, 32: 787-796. https://doi.org/10.1016/j.marpol.2008.03.022

Gold, B.D., Pastoors, M., Babb-Brott, D., Ehler, C., King, M., Maes, F., Mengerink, K., Müller, M., Pitta, T., Cunha, E., Ruckelshaus, M., Sandifer, P., \& Veum, K. (2011). Integrated Marine Policies and Tools Working Group. CALAMAR Expert Paper.

Halpern, B.S., Diamond, J., Gaines, S., Gelcich, S., Gleason, M., Jennings, S., Lester, S., Mace, A., McCook, L., McLeod, K., Napoli, N., Rawson, K., Rice, J., Rosenberg, A., Ruckelshaus, M., Saier, B., Sandifer, P., Sholtz, A., \& Zivian, A. (2012). Nearterm priorities for the science, policy and practice of Coastal and Marine Spatial Planning (CMSP). Marine Policy, 36: 198-205. https://doi.org/10.1016/j.marpol.2011.05.004

Healey, P. (1994). Development Plans: New Approaches to Making Frameworks for Land Use Regulation. European Planning Studies, 2(1): 39-57. https://doi.org/10.1080/09654319408720246

Healey, P. (1997). Collaborative Planning, Shaping Places in Fragmented Societies. Vancouver: University of British Columbia Press.

Healey, P. (2004). The Treatment of Space and Place in the New Strategic Spatial Planning in Europe. International Journal of Urban and Regional Research, 28.1: 45-67. https://doi.org/10.1111/j.0309-1317.2004.00502.x 
IOC-UNESCO \& EC-DGMARE (2017). The 2nd International Conference on Marine/Maritime Spatial Planning. Paris: UNESCO, IOC Workshop Reports Series.

Jameson, S., Tupper, M., \& Ridler, J. (2002). The Three Screen Doors: Can Marine Protected Areas be Effective? Marine Pollution Bulletin, 44(11): 1177-1183. https://doi.org/10.1016/S0025-326X(02)00258-8

Jay, S. (2013). From disunited sectors to disjointed segments? Questioning the functional zoning of the sea. Planning Theory \& Practice, 14(4): 509-525. https://doi.org/10.1080/14649357.2013.848291

Jay, S. (2018). The shifting sea: from soft space to lively space. Journal of Environmental Policy \& Planning, https://doi.org/10.1080/1523908X.2018.1437716

Jones, P.J.S., Lieberknecht, L.M., \& Qiu, W. (2016). Marine spatial planning in reality: Introduction to case studies and discussion of findings. Marine Policy, 71: 256-264, https://doi.org/10.1016/j.marpol.2016.04.026

Kelleher, G., \& Kenchington, R. (1991). Guidelines for Establishing Marine Protected Areas. A Marine Conservation and Development Report. Gland: IUCN.

Kidd, S., \& Ellis, G. (2012). From the Land to Sea and Back Again? Using Terrestrial Planning to Understand the Process of Marine Spatial Planning, Journal of Environmental Policy \& Planning, 14(1): 49-66. https://doi.org/10.1080/1523908X.2012.662382

Kidd, S., \& Shaw, D. (2014). The social and political realities of marine spatial planning: some land-based reflections. ICES Journal of Marine Science, 71(7): 1535-1541. https://doi.org/10.1093/icesjms/fsu006

Long R.D., Charles, A., \& Stephenson, R.L. (2015). Key principles of marine ecosystembased management. Marine Policy, 57: 53-60. https://doi.org/10.1016/j.marpol.2015.01.013

Margules, C.R., \& Pressey, R.L. (2000). Systematic conservation planning. Nature, 405: 243-253. http://doi.org/10.1038/35012251

Muniesa, F., \& Callon, M. (2008). La performativité des sciences économiques. [The performativity of economic sciences]. CSI Working Papers Series, 10: 1-23. Retrieved from https://halshs.archives-ouvertes.fr/halshs-00258130/document

OECD (2016). The Ocean Economy in 2030. Paris: OECD. http://dx.doi.org/10.1787/9789264251724-en

O'Leary, B. C., Winther-Janson, M., Bainbridge, J. M., Aitken, J., Hawkins, J.P., \& Roberts, C.M. (2016). Effective Coverage Targets for Ocean Protection. Conservation Letters, 9(6): 398-404. https://doi.org/10.1111/conl.12247

Olesen, K. (2014). The neoliberalisation of strategic spatial planning. Planning Theory, 13(3): 288-303. https://doi.org/10.1177/1473095213499340

Olsson, P., Folke, C., \& Hughes, T. (2008). Navigating the transition to ecosystem-based management of the Great Barrier Reef, Australia. Proceedings of the National Academy of Sciences of the USA, 105: 9489-9494. https://doi.org/10.1073/pnas.0706905105

Pendleton, L.H. et al. 2017. Marine Protected Areas: all articles. ICES Journal of Marine Science, Special issue, fsx178. https://doi.org/10.1093/icesjms/fsx178

Pınarbaşı, K., Galparsoro, I., Borja, Á., Stelzenmüller, V., Ehler, C.N., \& Gimpel, A. (2017). Decision support tools in marine spatial planning: Present applications, gaps 
and future perspectives. Marine Policy, 83: 83-91. https://doi.org/10.1016/j.marpol.2017.05.031

Qiu, W., \& Jones, P.J.S. (2013). The Emerging Policy Landscape for Marine Spatial Planning in Europe. Marine Policy, 39: 182-190. $\mathrm{http} / / /$ doi.org/10.1016/J.MARPOL.2012.10.010

Salet, W., \& Faludi, A. (Eds.) (2000). The Revival of Strategic Planning. Amsterdam: Royal Netherlands Academy of Arts and Sciences.

Sarkar, S., Pressey, R.L., Faith, D.P., Margules, C.R., Fuller, T., Stoms, D.M., \& Andelman, S. (2006). Biodiversity Conservation Planning Tools: Present Status and Challenges for the Future. Annual Review of Environment and Resources, 31(1): 123-159. https://doi.org/10.1146/annurev.energy.31.042606.085844

Schaefer, N., \& Barale, V. (2011). Maritime spatial planning: opportunities \& challenges in the framework of the EU integrated maritime policy. Journal of Coastal Conservation, 15(2): 237-245. https://doi.org/10.1007/s11852-011-0154-3

Slocombe, D.S. (1993). Environmental planning, ecosystem science, and ecosystem approaches for integrating environment and development. Environmental Management, 17(3): 289. https://doi.org/10.1007/BF02394672

Smith, H.D. (1988). The theory and practice of sea use management. In: Smith, H.D., \& Vigarié, A. (Eds.). New Frontiers in Marine Geography. Rome: Consiglio Nazionale delle Ricerche, 16-32.

Smith, H.D. (1990). Sea-Use Management and Planning in the North Sea. International Journal of Estuarine and Coastal Law, 5(1-3): 313-324.

Smith, H.D. (1991a). The North Sea: Sea use management and planning. Ocean and Shoreline Management, 16(3-4): 383-395. https://doi.org/10.1016/09518312(91)90015-T

Smith, H.D. (1991b). The regional bases of sea use management. Ocean and Shoreline Management, 15(4): 273-282. https://doi.org/10.1016/0951-8312(91)90020-3

Smith, H.D. (1994). The development and management of the world ocean. Ocean \& Coastal Management, 24(1): 3-16. https://doi.org/10.1016/0964-5691(94)90049-3

Smith, H.D., \& Lalwani, C.S. (1996). The North Sea: co-ordinated sea use management. GeoJournal, 39(2): 109-115. http://www.jstor.org/stable/41146924

Smith, H.D. (2000). The industrialisation of the world ocean. Ocean \& Coastal Management, 43(1): 11-28. https://doi.org/10.1016/S0964-5691(00)00028-4

Smith, H.D., Maes, F., Stojanovic, T.A., \& Ballinger, R.C. (2011). The integration of land and marine spatial planning. Journal of Coastal Conservation, 15: 291-303. https://doi.org/10.1007/s11852-010-0098-z

Sorensen, J. (2002). Baseline 2000 Background Report: The Status of Integrated Coastal Management as an International Practice (Second Iteration). Urban Harbors Institute Publications. Paper 31. Retrieved from $\mathrm{http}: / /$ scholarworks.umb.edu/uhi_pubs/31

Steinberg, P.E. (2001). The Social Construction of the Ocean. Cambridge: Cambridge University Press.

Stelzenmüller, V., Lee, J., South, A., Foden, J., \& Rogers, S.I. (2013). Practical tools to support marine spatial planning: A review and some prototype tools. Marine Policy, 38: 214-227. https://doi.org/10.1016/j.marpol.2012.05.038

Symes, D. (2005). Marine Spatial Planning: A Fisheries Perspective. Report to English Nature. Unpublished, 35. 
Whatmore, S., \& Boucher, S. (1993). Bargaining with Nature: The Discourse and Practice of 'Environmental Planning Gain'. Transactions of the Institute of British Geographers, 18(2): 166-178. https://doi.org/10.2307/622360

Wilson, E.O. (2016). Half-Earth: Our Planet's Fight for Life. London: Liveright Publishing.

Woodcock, P., O’Leary, B.C., Kaiser, M.J., \& Pullin, A.S. (2017). Your evidence or mine? Systematic evaluation of reviews of marine protected area effectiveness. Fish and Fisheries, 18(4): 668-681. https://doi.org/10.1111/faf.12196

World Parks Congress (2014). A strategy of innovative approaches and recommendations to enhance implementation of marine conservation in the next decade. Retrieved from http://worldparkscongress.org/downloads/approaches/ThemeM.pdf

Young, E., \& Fricke, P. (Eds.) (1975). Sea-use Planning. Fabian Tract, 337: 1-36. Retrieved from https://digital.library.lse.ac.uk/objects/lse:top483tin/read/single\#page/38/mode/2up 
824 Table 1. Evolution of the added value of the global ocean economy (in USD). OECD, 2016.

825

\begin{tabular}{|l|l|ll|}
\hline Ocean-related sectors & $\mathbf{2 0 1 0}$ & $\mathbf{2 0 3 0}$ & Evol. 2010-2030 \\
\hline Maritime and coastal tourism & 390107246153 & 777138485595 & $99,21 \%$ \\
\hline Offshore oil and gas & 504034800805 & 636089807812 & $26,20 \%$ \\
\hline Port activities & 193000000000 & 472850000000 & $145,00 \%$ \\
\hline Maritime equipment & 168034658400 & 299674237328 & $78,34 \%$ \\
\hline Fish processing & 78806980720 & 265601462945 & $237,03 \%$ \\
\hline Offshore wind & 2867787104 & 230472860260 & $7936,61 \%$ \\
\hline Water transport & 82594084254 & 118023313343 & $42,90 \%$ \\
\hline Shipbuilding and repair & 57693008821 & 102890133394 & $78,34 \%$ \\
\hline Industrial capture fisheries & 21081783838 & 47048622903 & $123,17 \%$ \\
\hline Industrial marine aquaculture & 3627080903 & 10964638511 & $202,30 \%$ \\
\hline & 1501847430997 & 2960753562090 & $97,14 \%$ \\
\hline
\end{tabular}

826

827 Figure 1. Distribution of the 44 MSP initiatives analysed

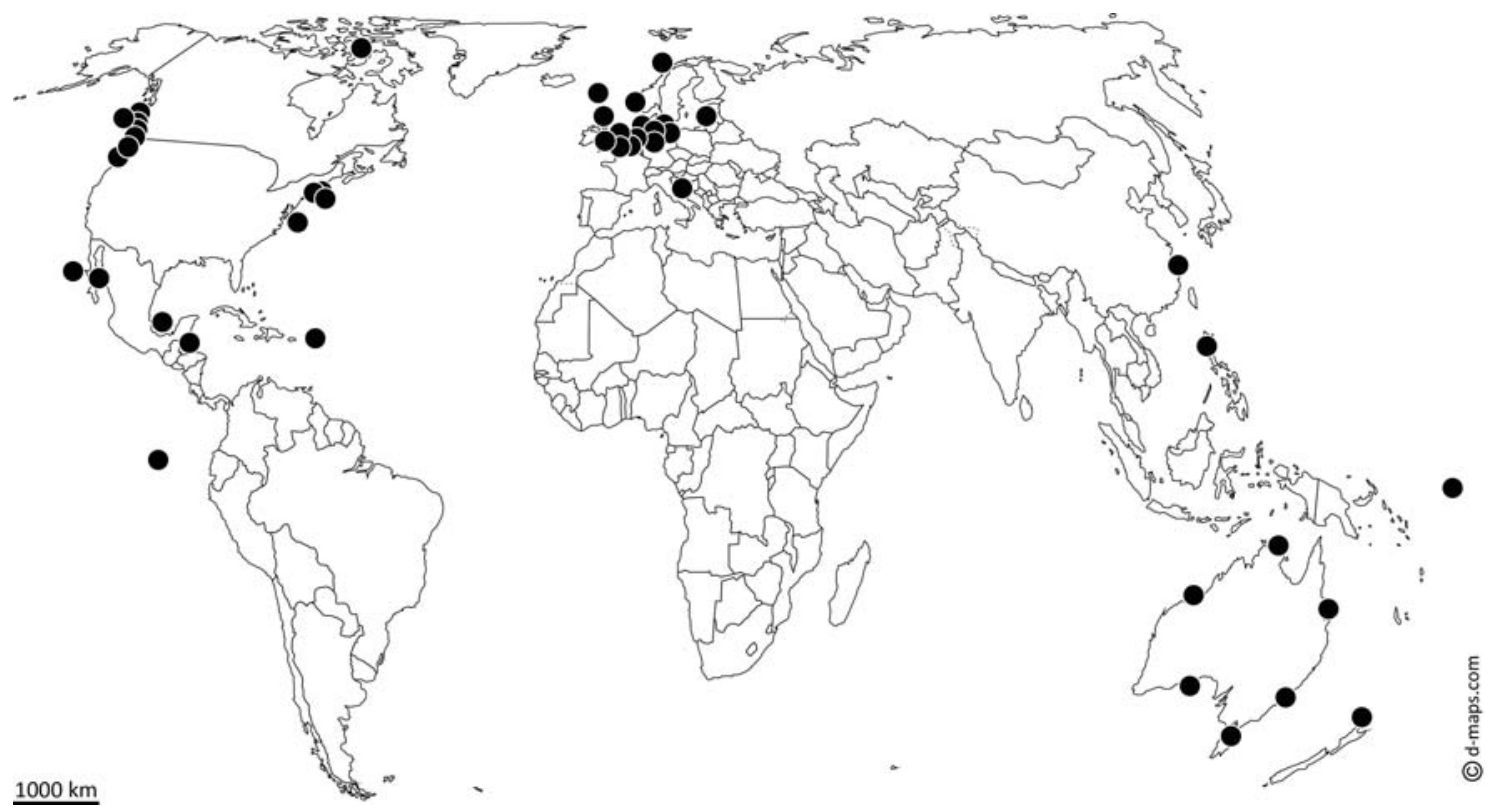

829 
831 Figure 2. Identification of MSP publication groups using an influence graph.

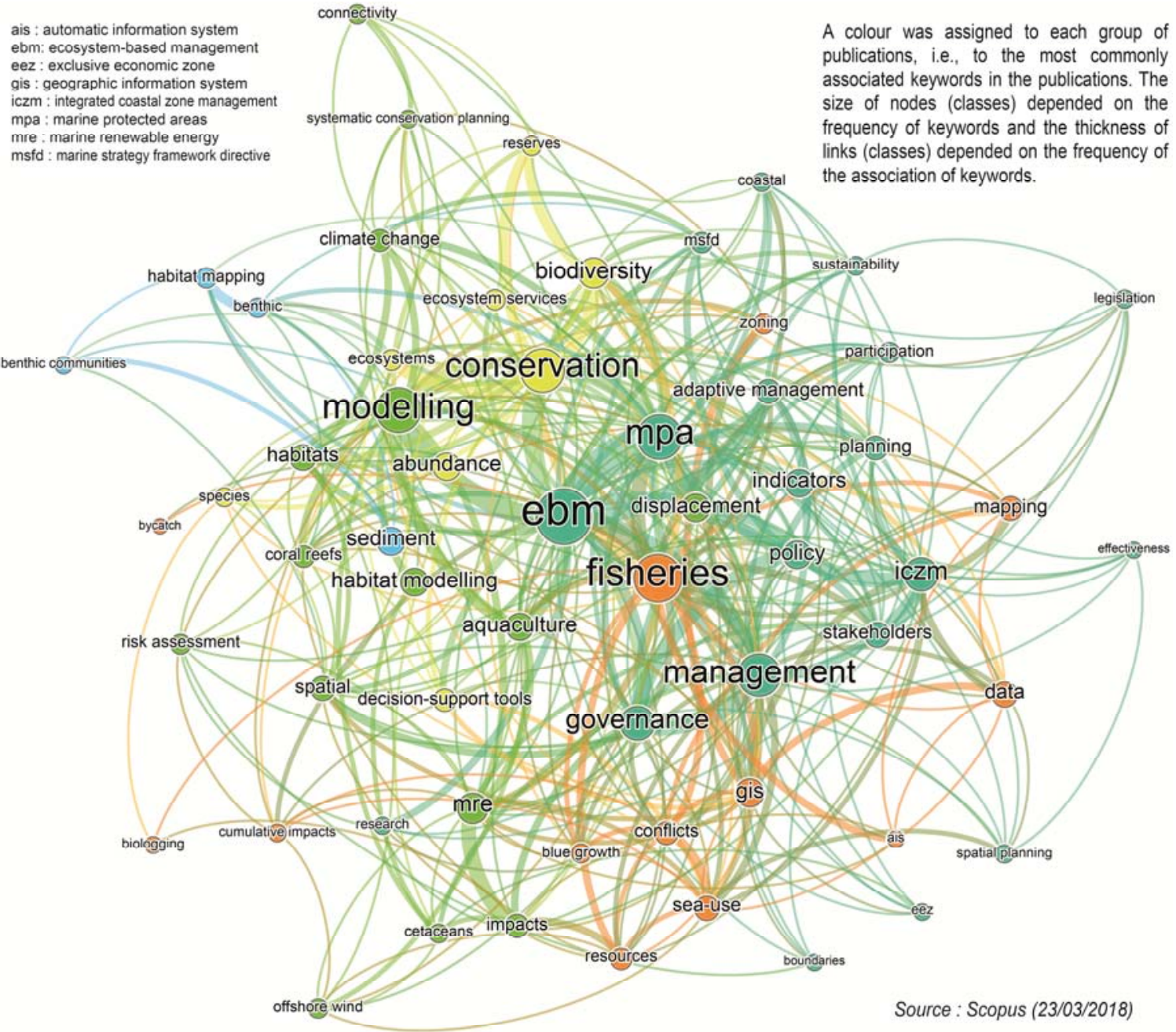

Method:

1/ A Scopus query was made on the terms "marine spatial planning" or "maritime spatial planning" in the title, abstract or keywords (listed by the authors), restricting the search to articles published or to be published in scientific journals (i.e., excluding indexed books). The two oldest articles dated from 2004 and the search was made on 31/03/2018. Result $=735$ publications.

2/ Extraction of all keywords.

3/ Cleaning the data file involved: deletion of toponyms, names of organisations and adjectives (e.g. marine, maritime, oceanic, etc.), except when specialisation conserved meaning (e.g. "coral reefs" vs, "artificial reefs"), case standardisation, harmonisation of the use of the singular or plural and generalisation of certain keywords (e.g., "data" 635 items with at least one keyword.

4/ Main stages of the construction of the influence graph with Gephi 0.92 : import of the file as an adjacency list (non-directed graph) comprising 902 nodes (different keywords) and 2116 links (one keyword was linked to another if it appeared in the same list for an article), filter performed on the degree range (60 nodes retained and 416 links), "atlas force" spatialisation mode (making it possible to show "communities"). partition of nodes from modularity statistics.

Main limitations: 
835 Table 2. Indicators used to analyse MSP initiatives.

\begin{tabular}{|c|c|c|}
\hline Indicator & Code & Label \\
\hline \multirow[t]{4}{*}{ Size of the planning area } & I1 & $0-19,999 \mathrm{~km}^{2}$ \\
\hline & & $20,000-99,999 \mathrm{~km}^{2}$ \\
\hline & & $100,000-499,999 \mathrm{~km}^{2}$ \\
\hline & & $500,000-2,000,000 \mathrm{~km}^{2}$ \\
\hline \multirow[t]{2}{*}{ Content of the planning document } & $\mathrm{I} 2$ & $\begin{array}{l}\text { The content is single-sector focused or } \\
\text { conservation-focused (other issues are poorly } \\
\text { documented) }\end{array}$ \\
\hline & & $\begin{array}{l}\text { The content is broad and includes a large range } \\
\text { of sectors and conservation issues. }\end{array}$ \\
\hline \multirow[t]{3}{*}{ MSP Orientations } & $\mathrm{I} 3$ & Ecosystem-based MSP (hard sustainability) \\
\hline & & Integrated-use MSP (soft sustainability) \\
\hline & & Other/Non applicable \\
\hline \multirow[t]{2}{*}{$\begin{array}{l}\text { Spatially-explicit strategic orientations in the } \\
\text { planning document }\end{array}$} & I4 & Yes \\
\hline & & No \\
\hline \multirow[t]{2}{*}{ Role given to zoning } & I5 & $\begin{array}{l}\text { Strategic orientations are given through a zoning } \\
\text { plan OR a zoning plan is presented }\end{array}$ \\
\hline & & $\begin{array}{l}\text { Strategic orientations are not given through a } \\
\text { zoning plan. }\end{array}$ \\
\hline \multirow[t]{2}{*}{ Accuracy of mapping features } & I6 & $\begin{array}{l}\text { There is an accurate zoning plan OR a spatial } \\
\text { vision is precisely expressed }\end{array}$ \\
\hline & & $\begin{array}{l}\text { A zoning plan OR a spatial vision is fuzzily } \\
\text { expressed }\end{array}$ \\
\hline \multirow[t]{2}{*}{ Prescriptive/indicative } & I7 & $\begin{array}{l}\text { The zoning OR the spatial vision expressed is } \\
\text { prescriptive }\end{array}$ \\
\hline & & $\begin{array}{l}\text { The zoning OR the spatial vision expressed is } \\
\text { indicative }\end{array}$ \\
\hline
\end{tabular}


Table 3. Raw results.

\begin{tabular}{|c|c|c|c|}
\hline Code & Value & Count & Comments \\
\hline \multirow[t]{5}{*}{ I1 } & 1 & 16 & \multirow{4}{*}{$\begin{array}{l}\text { Information was missing for } 8 \text { planning areas (see Appendix 1c). Due to the size of the } \\
\text { classes, a rough evaluation was done to sort the cases into the six size classes. }\end{array}$} \\
\hline & 2 & 9 & \\
\hline & 3 & 10 & \\
\hline & 4 & 9 & \\
\hline & Sub. & 44 & \\
\hline \multirow[t]{3}{*}{$\mathrm{I} 2$} & 1 & 7 & \multirow{2}{*}{$\begin{array}{l}\text { Considering that MSP is not a substitute for single-sector planning and is not } \\
\text { conservation-only planning either (see http://msp.ioc-unesco.org/about/marine-spatial- } \\
\text { planning/), I2 is dedicated to checking the content of the planning document, which } \\
\text { sometimes gives an indication on its orientation. Details in Appendix 1d. }\end{array}$} \\
\hline & 2 & 37 & \\
\hline & Sub. & 44 & \\
\hline \multirow[t]{4}{*}{ I3 } & 1 & 15 & \multirow{2}{*}{$\begin{array}{l}\text { I3 is dedicated to interpreting the way to consider sustainability in the plan. In some } \\
\text { cases, it is obviously not easy to interpret whether the approach is that of hard or soft } \\
\text { sustainability. Some arguments and explanations are given in Appendix 1d (see } \\
\text { comments). In addition, the main orientations are summarized in Appendix 1d. Those } \\
\text { between parentheses have been interpreted as secondary. }\end{array}$} \\
\hline & 2 & 27 & \\
\hline & 0 & 2 & \\
\hline & Sub. & 44 & \\
\hline \multirow[t]{3}{*}{ I4 } & 1 & 24 & $\begin{array}{l}\text { I4 is dedicated to interpreting the combination of strategic and spatial dimensions of } \\
\text { the planning process. A strategic vision is not always expressed spatially, and } \\
\text { conversely a spatial vision is not always strategic. Details in Appendix 1e. }\end{array}$ \\
\hline & 0 & 20 & \\
\hline & Sub. & 44 & \\
\hline \multirow[t]{3}{*}{ I5 } & 1 & 19 & \multirow{2}{*}{$\begin{array}{l}\text { I5 is dedicated to interpreting the way the strategic orientations are expressed. These } \\
\text { can be expressed through objectives (for instance, in terms of extension/development } \\
\text { but without specifying where). It can also be expressed either by a zoning plan (I5) or } \\
\text { in another way that gives a "spatial vision" (ex. scenario) (I6). One should also note } \\
\text { that there is sometimes a zoning plan without a strategic dimension expressed (most of } \\
\text { the time here, this is because the zoning plan already exists). In few cases, there is a } \\
\text { zoning map (I4) without any explicit strategic orientation. Details in Appendix 1e. }\end{array}$} \\
\hline & 0 & 25 & \\
\hline & Sub. & 44 & \\
\hline \multirow[t]{3}{*}{ I6 } & 1 & 28 & \multirow[t]{2}{*}{$\begin{array}{l}\text { I6 is dedicated to interpreting whether the zoning plan (or the "spatial vision") is } \\
\text { mapped with accuracy or, conversely, in a fuzzy manner. Details in Appendix 1e. }\end{array}$} \\
\hline & 0 & 2 & \\
\hline & Sub. & 30 & \\
\hline \multirow[t]{3}{*}{ I7 } & 1 & 12 & \multirow{2}{*}{$\begin{array}{l}\text { Complementarily, I7 is dedicated to interpreting whether the zoning plan (or the } \\
\text { "spatial vision") is prescriptive or indicative. Details in Appendix 1e. }\end{array}$} \\
\hline & 0 & 18 & \\
\hline & Sub. & 30 & \\
\hline
\end{tabular}


843 Figure 3. Classifying MSP initiatives by type.

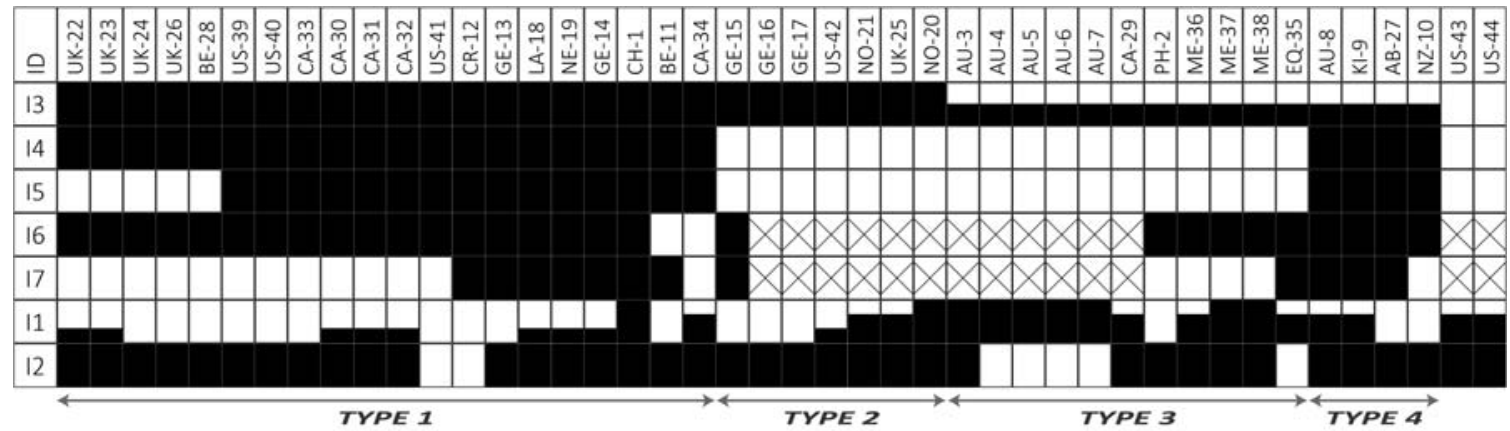

\footnotetext{
Content: single-sector or conservation focused / integrated

13 Sustainability : non applicable / hard / soft

14 Planning: Strategic/Spatial

15 Zoning: no/ves

16 Zoning or spatial vision: fuzzy / accurate / non-applicable

17 $\square$ Zoning (or spatial vision): indicative / prescriptive / non-applicable
}

For details, see supplementary material (Appendix 1b-f)

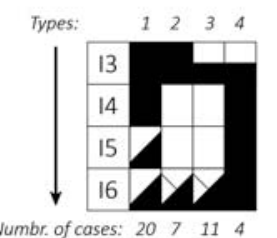

1: soft sustainability + spatial + accurate zoning or spatial vision

2: soft sustainability + strategic

3: hard sustainability + strategic

4: hard sustainability + spatial + accurate zoning

5: other cases (2)

NB: No significant correlation with 11,12 and 17 .

Figure 4. The two main facets of MSP.

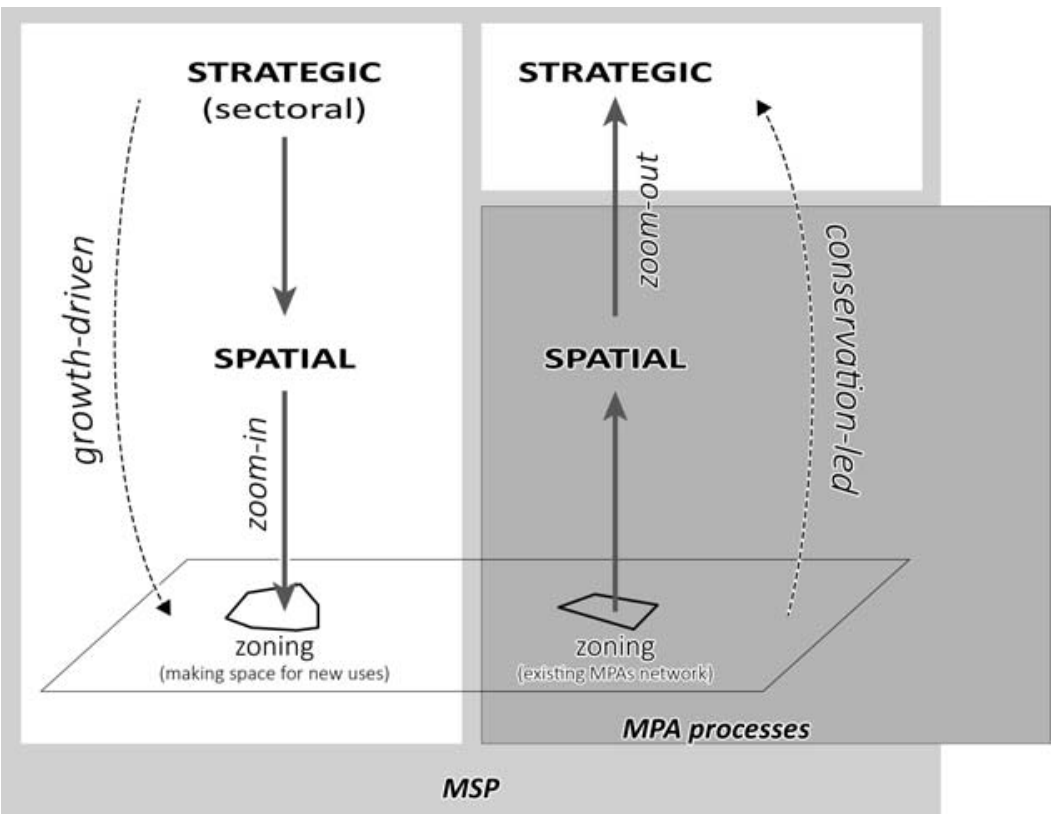

